\title{
1 Rethinking the Contribution of Drained and Undrained 2 Grasslands to Sediment Related Water Quality Problems
}

3

\author{
G. S. Bilotta*1, ${ }^{1,}$, R. E. Brazier ${ }^{1}$, P. M. Haygarth ${ }^{2}$, C. J. A. Macleod ${ }^{2}$, P. Butler ${ }^{2}$, S. \\ Granger $^{2}$, T. Krueger ${ }^{3}$, J. Freer ${ }^{3}$, J. Quinton ${ }^{3}$
}

1) Geography Department, University of Exeter, Amory Building, Rennes Drive, Exeter, Devon, EX4 4RJ, United Kingdom.

2) Cross Institute Programme for Sustainable Soil Function, Institute of Grassland and Environmental Research, North Wyke, Okehampton, Devon, EX20 2SB, United Kingdom. 3) Lancaster Environment Centre, Lancaster University, Lancaster, LA1 4YQ, United Kingdom.

* Corresponding author: gary.bilotta@bbsrc.ac.uk

\section{Abstract}

Grass vegetation has long been recommended for use in the prevention and control of soil erosion because of its dense sward characteristics and stabilising effect on the soil (e.g. Morgan and Rickson, 1995). As a consequence, there has been a general assumption that grassland environments suffer from minimal soil erosion and therefore present little threat to the water quality of surface waters, in terms of sediment and sorbed contaminant pollution (Nash and Halliwell, 1999; Sharpley et al., 2000). However, we present data that questions this assumption, reporting results from one hydrological year of observations on a fieldexperiment monitoring overland flow, drain flow, and fluxes of suspended solids (SS), total phosphorus (TP), and molybdate-reactive phosphorus (MRP, $<0.45 \mu \mathrm{m}$ ), in response to natural rainfall events. Results show that during individual rainfall events, 1-ha grassland lysimeters yield up to $15 \mathrm{~kg}$ of suspended solids, with concentrations in runoff waters of up to $400 \mathrm{mg} \mathrm{L}^{-1}$. These concentrations would exceed the water quality standards recommended by 
1 both the European Freshwater Fisheries Directive $\left(25 \mathrm{mg} \mathrm{L}^{-1}\right)$, and the United States

2 Environmental Protection Agency $\left(80 \mathrm{mg} \mathrm{L}^{-1}\right)$, and are beyond those reported to have caused

3 chronic effects on freshwater aquatic organisms (e.g. Ryan, 1991). Furthermore, TP

4 concentrations in runoff waters from these field lysimeters exceeded $800 \mu \mathrm{g} \mathrm{L}^{-1}$. These

5 concentrations are in excess of those reported to cause serious eutrophication problems in

6 both rivers and lakes (OECD, 1982), and would contravene the ecoregional nutrient criteria in

7 all of the U.S. ecoregions (U.S. Environmental Protection Agency, 2007). This paper also

8 examines how subsurface drainage, a common agricultural practice in intensively managed

9 grasslands, influences the hydrology and export of sediment and nutrients from grasslands.

10 This data-set suggests that we need to rethink the conceptual understanding of grasslands as

11 non-erosive landscapes. Failure to acknowledge this will undoubtedly result in the non-

12 compliance of surface waters to water quality standards.

14 Abbreviations: Total Phosphorus (TP), Molybdate-Reactive Phosphorus (MRP), Suspended

15 Solids (SS), Volatile Organic Matter (VOM), Interflow (IF), Drainflow (DF).

\section{Introduction}

18 Water quality is a term used to describe the physical (e.g. turbidity, temperature) and chemical (e.g. dissolved oxygen, nitrate, phosphorus, $\mathrm{pH}$ levels) properties of a water body. Water quality provides an indicator of ecosystem health and can be used to identify potential sources

21 of environmental pollution. Suspended solids are organic and inorganic particulate matter that

22 is transported in the water column. These particulates influence both the physical and

23 chemical properties of surface waters. For example, suspended solids can cause a physical 
1 change in waters by increasing turbidity, thereby reducing light penetration through the water

2 column, impacting on benthic organisms such as rooted macrophytes and benthic

3 invertebrates. Suspended solids can cause a chemical change in waters by acting as a vector of

4 sorbed contaminants from the land surface, such as phosphorus (e.g. Heathwaite et al., 2005),

5 pathogens (e.g. Oliver et al., 2005) and pesticides (e.g. Morgan, 2005). In combination, these

6 alterations to water quality can lead to undesirable effects such as eutrophication, which

7 results in a shift in ecosystem community structure, reduced biodiversity, and deterioration of

8 the water resource used for recreational purposes and as a source of potable water. Soil

9 erosion by water is a major source of suspended solids in surface waters, and consequently,

10 there has been a large amount of research input into quantifying and controlling this process,

11 particularly on agricultural land considered to be susceptible to erosion. However, a review of

12 the soil erosion literature (see Boardman and Evans, 1994; Brazier, 2004; Evans, 2005, for

13 comprehensive examples), reveals that almost all of this research relates to erosion on

14 lowland arable land or upland areas, with a general implicit assumption that lowland,

15 intensively managed grassland is devoid of erosion processes and therefore does not contribute, or contributes minimally, to sediment-related water quality problems (Brazier et al., 2007). Historically, it has been understandable that the focus of erosion work has been on land-use types that were considered to be more susceptible and where, for example, on-site soil erosion was removing significant quantities of topsoil and threatening agricultural productivity. Evidence from numerous small-scale laboratory experiments (e.g. De Baets et al., 2006; Pan and Shangguan, 2006; Pearce et al., 1997) and small-scale field plot experiments (e.g. Davies et al., 2006; Fullen, 1992; Fullen et al., 2006) suggested that the type of vegetation cover found in grasslands would prevent significant on-site losses of soil

24 through soil erosion because the process is retarded where swards intercept raindrop energy, 25 slow overland flow, trap particulates, and stabilise the soil structure, hence the use of grass 
vegetation in buffer strips. More recently though, a shift in emphasis away from preventing on-site soil losses to increase agricultural productivity, towards more sustainable agriculture and the need to preserve water quality (Neal and Jarvie, 2005), necessitates that we re-assess the contributions of all land-surfaces to the loads of suspended solids in catchment surface waters.

In terms of studying soil erosion, this should translate into a move away from simple, smallscale laboratory and field-plot experiments on vegetated surfaces, towards larger scale studies which incorporate the conditions and processes that are observed at the landscape scale which have frequently been neglected in previous studies, despite the fact that globally, the majority of temperate lowland grasslands are managed in an intensive agricultural manner (Peeters, 2004; Reynolds and Frame, 2005). These previously neglected processes include the important effects of grazing animals (Bilotta et al., 2007), the presence of subsurface drainage pathways (Armstrong and Garwood, 1991), the effect of farm vehicle traffic, and the application of animal manures and slurry (Haygarth et al., 2006). There is a risk of policy failure if the existing understanding of erosion from vegetated surfaces, which is often based on simple laboratory simulations or small-scale plot experiments, is used to guide land management and mitigation decisions, if for example, the results were used to warrant the conversion of arable land to intensively managed grassland in the quest to solve erosion and water quality problems. This paper presents event-scale budget dynamics from drained and undrained intensively managed grasslands, thus providing novel information to answer two key questions: (1) To what extent do intensively managed grasslands contribute to sedimentrelated water quality problems? and (2) What influence does the presence of subsurface drainage have on the export of suspended sediment and sorbed contaminants from intensively managed grasslands? 
Materials and Methods

\section{FIGURE 1 HERE}

The field site is based at Rowden, in Devon (UK) (Latitude 50.7802, Longitude -3.9153), described in more detail by Armstrong and Garwood (1991). Figure 1 is a location map and aerial photograph of the field-site. The site is divided into 1-ha, hydrologically isolated, fieldscale lysimeters, two of which are used in this study: one lysimeter with artificial drainage and one lysimeter without (Figure 2). The site and lysimeters were originally established in 1982 on old unimproved grassland on slowly permeable sloping land (5-10\%) (Scholefield et al., 1993). The soil at the Rowden site is classified as a clayey non-calcareous pelostagnogley (Avery, 1980), a Typic Haplaquept (USDA, 1975) of the Hallsworth Series. This soil series represents the most common hydrologic soil type in England and Wales, covering approximately $13.9 \%$ of the land area, according to the Hydrology of Soil Types classification system - HOST, (Boorman et al., 1995), and is typical for many areas where grassland production predominates (Wilkins, 1982). The long-term mean annual rainfall at this site is $1055 \mathrm{~mm}$, which is considered to be representative of much of the UK intensively managed grasslands (Smith and Trafford, 1976). Application of fertilisers at the Rowden site is in accordance of the 'Code of Good Agricultural Practice' (Defra, 2003) and is therefore considered to represent standard management practices for grassland soils. During the three years prior to this monitoring, fertiliser application on both lysimeters had been at a rate of 250, 25, and $50 \mathrm{~kg} \mathrm{yr}^{-1}$ for $\mathrm{N}, \mathrm{P}$, and $\mathrm{K}$ nutrients respectively. The total phosphorus level in the bulked surface soil $(0-20 \mathrm{~cm})$ of the lysimeters is approximately $540 \mathrm{mg} \mathrm{kg}^{-1}$ (Haygarth et al., 1998). The lysimeters are grazed by beef cattle every year throughout the months of June to October. The stocking density for these lysimeters was managed to control sward height $(8-10 \mathrm{~cm})$, but averaged four livestock units per hectare. Livestock grazing the 
1 lysimeters carry out three key activities which may impact on the sediment-related water

2 quality from grassland environments; (1) defoliation, reducing vegetation cover, (2) treading,

3 compacting, pugging and poaching the soil, and (3) excretion, providing a readily-available

4 source of particulate colloidal material and phosphorus (Bilotta et al., 2007).

The drainage of the drained lysimeter is achieved using mole drains drawn downslope at $2 \mathrm{~m}$ spacing and at $55 \mathrm{~cm}$ soil depth. These mole drains cross permanent pipe drains (>100 $\mathrm{mm}$ diameter) at $40 \mathrm{~m}$ spacing and $85 \mathrm{~cm}$ soil depth, with permeable backfill to within $30 \mathrm{~cm}$ of the surface (see Figure 2). Deep interceptor drains were installed to divert extraneous water at upslope boundaries, thus hydrologically isolating each lysimeter. Although there is potential

11 for deep seepage from the lysimeters, this is considered to be negligible for a subsoil with such low hydraulic conductivity $\left(<10 \mathrm{~mm} \mathrm{day}^{-1}\right)$ (Armstrong and Garwood, 1991). The placement of extra interceptor drains reduced the possibility of deep seepage into the lysimeters by water moving downslope under pressure. Flow monitoring on the undrained lysimeter amalgamates overland flow plus subsurface throughflow to a depth of $30 \mathrm{~cm}$. The combined flow (herein called interflow) is collected in gravel-filled ditches installed at $30 \mathrm{~cm}$ depth at the lower lysimeter boundary. This flow then passes through a standard $45^{\circ} \mathrm{v}$-notch weir where stage is measured via a head recording device and is recorded at 1-min intervals. On the drained lysimeter the interflow pathway is monitored in exactly the same way as in the undrained lysimeter, but in addition, there is a second, separate v-notch weir through which

21 the flow from the artificial mole and pipe drains is measured.

As outlined above, the lysimeter weirs record stage (h). To convert $h$ to discharge $(\mathrm{Q})$, a stage-discharge relationship was produced from an experiment during July 2006 which involved 470 measurements of discharge at the full range of stages on these weirs. This was 
1 used to produce a classic non-linear least squares fit of a $4^{\text {th }}$ order polynomial. Furthermore,

2 due to the overriding importance of hydrology in determining sediment and nutrient loads and

3 budgets, estimates of the errors associated with the calibration technique (e.g. measurement

4 error, timing error, spillage error), were used to produce uncertainty intervals (maximum and

5 minimum) for discharge at any given stage. This technique was developed by Krueger et al.

6 (2007) based on an adaptation of the fuzzy rating curve concept of Pappenberger et al. (2006).

7 Rainfall was measured using a tipping-bucket rain gauge (Rainwise, USA) which recorded

8 the total number of tips $\min ^{-1}$ (each tip equivalent to $0.254 \mathrm{~mm}$ rainfall).

10 Water samples were collected throughout the 2005-2006 hydrological season using ISCO automated pump samplers with intake tubing that had depth-integrated inlets located in the outlet pipes of the relevant hydrological pathway. The ISCO samplers were programmed to sample on discrete time-steps, of no more than 60 mins, throughout storm events based on weather forecasts. These samples were transferred into $1000 \mathrm{~mL}$ polyethylene bottles within $24 \mathrm{~h}$ and then immediately refrigerated on return to the laboratory, with the TP sample being transferred to polypropylene autoclavable bottles, within $24 \mathrm{~h}$, as suggested by the sample storage protocol described in Haygarth et al. (1995). Samples were analysed for concentrations of suspended solids (SS), volatile organic matter (VOM), total phosphorus (TP), and where possible, molybdate reactive phosphorus (MRP) $(<0.45 \mu \mathrm{m})$. The method for analysis of SS and VOM is described by Anon (1980). Briefly, this involves filtration of a 21 known volume of sample through a pre-weighed, dry, glass-fibre filter paper (Whatman GF/F $0.70 \mu \mathrm{m}$ pore size), followed by drying at $105^{\circ} \mathrm{C}$ for $60 \mathrm{~min}$ and re-weighing to determine SS, followed by furnacing at $500{ }^{\circ} \mathrm{C}$ for $30 \mathrm{~min}$ and re-weighing to determine VOM. The method used to determine concentrations of TP was acid persulfate digestion of $20 \mathrm{ml}$ aliquots of each sample, using a method adapted from Eisenrich et al. (1975). Absorbance was calibrated on a 
spectrophotometer (Cecil) using six standard solutions of potassium di-hydrogen phosphate in the range of $0-500 \mu \mathrm{g} \mathrm{L}^{-1} \mathrm{P}$, prepared fresh on each day of analysis. Concentrations of MRP $(<0.45 \mu \mathrm{m})$ were also determined colorimetrically with a spectrophotometer (Cecil) after filtration of the sample (within $24 \mathrm{~h}$ of collection) through a $0.45 \mu \mathrm{m}$ cellulose nitrate filter paper (Whatman) followed by reaction with molybdate, ascorbic acid and antimony potassium tartrate (see Murphy and Riley, 1962).

Budgets of SS and TP were calculated using linear interpolation of point concentration data, followed by multiplication of these interpolated data by the corresponding discharge data $(\mathrm{L}$ $\min ^{-1}$ ) to produce loads $\min ^{-1}$ with an assessment of uncertainty incorporated as minimum and maximum loads. The event budgets shown are the sum of these 1-min interpolated loads. This is considered to be a reasonable technique given the high frequency of sampling; however, all load estimation techniques apply assumptions and include uncertainties which we need to be aware of, although they are not analysed in detail in this paper (Krueger et al,. 2007).

\section{FIGURE 2 HERE}

\section{Results and Discussion}

Figure 3 shows hydrographs illustrating the typical observed behaviour of drained and undrained 1-ha grassland lysimeters in response to natural rainfall events. Table 1 is a summary table of the event budgets for drained and undrained 1-ha grassland lysimeters for five separate monitored events. Figure 4 is a hydrograph of the 2005-2006 hydrological season for the drained lysimeter. Figure 4 shows that the events analysed in this paper are not the only events that occurred (approximately 25 events of similar magnitude occurred over the season), they reflect the events that were successfully captured on both lysimeters over 
comparable time periods. The 2005-2006 hydrological year was unusually dry, with just $60 \%$ lysimeters is environmentally significant in terms of sediment-related water quality issues. can yield up to $14.85 \mathrm{~kg}$ of SS (12.59 - $16.75 \mathrm{~kg}$ considering discharge uncertainty estimation) in response to individual rainfall events lasting less than $24 \mathrm{~h}$ (Table 1). The observed exports of suspended solids from the grassland field lysimeters are surprising given the conventional perception of grasslands as low-erosion landscapes. For example, Alström and Åkerman (1992) observed that annual rates of erosion from arable land in Sweden varied from as little as $1 \mathrm{~kg} \mathrm{ha}^{-1} \mathrm{yr}^{-1}$ to $16 \mathrm{t} \mathrm{ha}^{-1} \mathrm{yr}^{-1}$. Kronvang et al. (1997) monitored suspended sediment losses from Danish arable land and estimated annual losses of between 71 to $88 \mathrm{~kg} \mathrm{ha}^{-1} \mathrm{yr}^{-1}$. Withers et al. (2006) observed rates of erosion at an arable site in England to vary between 75 to 650 $\mathrm{kg} \mathrm{ha}^{-1} \mathrm{yr}^{-1}$. Therefore, rates of erosion from these 1-ha grassland fields are within the ranges published for rates of erosion from arable land - a land-use that is considered to be susceptible to erosion.

\section{FIGURE 3 HERE} FIGURE 4 HERE

Concentrations of SS in runoff waters from the field-scale lysimeters were also higher than might be expected, reaching highs of $385 \mathrm{mg} \mathrm{L}^{-1}$ (drained lysimeter). To put this into context, the European Freshwater Fisheries Directive suggests that concentrations of SS above $25 \mathrm{mg}$ $\mathrm{L}^{-1}$ are harmful to salmonid and cyprinid fish populations. Furthermore, a study by Gammon (1970), which was used to develop the United States Environment Protection Agency's water quality criteria, reported that SS concentrations of $80 \mathrm{mg} \mathrm{L}^{-1}$ caused a $60 \%$ decrease in the density of macro-invertebrates in streams. Clearly, the erosion from these grassland 
1 As can be seen in Table 1, the composition of the suspended solids exported from the field-

2 scale grassland lysimeters is dominated by mineral matter $(66-87 \%)$. The percentage of

3 suspended solids exported from the grassland lysimeters in the form of volatile organic matter

4 (VOM) ranged from $13 \%$ to $34 \%$ (of the total amount of SS export from the lysimeter, not the

$5 \%$ of SS as VOM in individual pathways). The VOM data provides evidence to support the

6 contention that it is the process of erosion in these grasslands that is the main contributor to

7 sediment-related water quality problems and not just incidental runoff of livestock wastes

8 deposited/applied on the grassland surface. If the latter was the case, then we would expect

9 the suspended solids transported in runoff to be predominantly composed of VOM, not

10 mineral matter. Table 1 shows that the percentage of SS export in the form of VOM tends to

11 be highest in the drainflow pathway compared to the interflow pathway, with up to $51 \%$ of SS export in drainflow occurring in the form of VOM. This may be due to the lower erodibility

13 of the subsurface pathway compared to the surface pathway. Therefore as there is less mineral 14 matter being eroded in the subsurface pathway, there is a relative increase in the percentage of

15 VOM being exported in that pathway. Nevertheless, because the majority of SS export from the drained lysimeter occurs via the interflow pathway (62-76\%), the net composition of SS exported from the drained lysimeter reflects the composition of SS in the interflow pathway more than the drain pathway.

The results also demonstrate that 1-ha grassland fields can yield up to $50 \mathrm{~g}$ of phosphorus (42

$21-55 \mathrm{~g}$ considering discharge uncertainty estimation) in response to individual rainfall events (Table 1). Concentrations of TP in runoff waters from the field lysimeters reached highs of more than $800 \mu \mathrm{g} \mathrm{L}^{-1}$. To put this into perspective, the Organisation for Economic Cooperation and Development suggest that eutrophication problems can be triggered by TP 
1 concentrations as low as $35-100 \mu \mathrm{g} \mathrm{L}^{-1}$ (OECD, 1982). Clearly, these grasslands are a

2 serious threat to water quality in terms of phosphorus loading and eutrophication.

3 The percentage of the total amount of TP exported from the grassland lysimeters in the form

4 of MRP $(<0.45 \mu \mathrm{m})$ ranged from 8 to $18 \%$ (Table 1$)$. This implies that the majority of TP

5 export from these intensively managed grasslands is facilitated by sediment and colloids (i.e.

6 sorbed to particle surfaces and in non-dissolved forms).

The export of SS and TP from these grassland lysimeters varies with the amount of rainfall and antecedent moisture conditions, but also appears to be influenced by the presence of subsurface drainage. Examination of Table 1 reveals that the export of SS and TP was higher

11 from the undrained land than from the drained land. The mass of SS and TP exported from the drained land was as much as $52 \%$ lower than that from undrained land during the same storm event. Statistical T-tests on SS and TP load data from undrained and drained land confirm that this difference in mass export from drained and undrained land is significantly different ( $\mathrm{p}$ $<0.001$ ) for all rainfall events (i.e. consistently higher loads of SS and TP from undrained land), except for the 1st December 2005 event.

The causes of the observed difference in SS and TP export from drained and undrained land may be numerous and complex, but hydrology, as the driver of erosion processes, is the primary factor we consider here. There are three main ways in which the hydrology of the

21 drained land differs from that of the undrained land; (1) Quantity, (2) Pathway, and (3) Timing. The mechanisms by which these factors help to account for the differences in SS and TP export between drained and undrained land, are discussed below: 
1 First, both the total discharge (L), and the peak discharge $\left(\mathrm{L} \mathrm{s}^{-1}\right)$, from drained land tend to be

2 lower than that from undrained land during the same rainfall events (Table 1 and Figure 3).

3 This difference can be as high as $50 \%$. This is contrary to the findings of some workers (e.g.

$4 \quad$ Hart, 1979; Howe et al., 1967; Robinson et al., 1985), who propose that subsurface drainage

5 is associated with higher peak discharges and faster runoff response to rainfall events. We

6 suggest that this is not the case at the Rowden site for the following reason; the soil in

7 undrained land remains saturated or near saturation for a large proportion of the hydrological

8 season. This is because vertical hydraulic conductivity (percolation) is seriously impeded by

9 the dense clay subsoil present at $30 \mathrm{~cm}$ soil depth, and lateral hydraulic conductivity

10 (throughflow) is very slow in the surface soil horizon. As a consequence of this, saturation-

11 excess overland flow occurs readily in response to rainfall events during the hydrological

season. On the drained land, however, subsurface drainage acts to lower the zone of saturation

13 in the soil by improving vertical hydraulic conductivity, allowing water to percolate vertically

14 away from the surface and into the drains. This hydrological effect of subsurface drainage,

15 has been observed in previous studies (e.g. Armstrong, 1986; Armstrong and Garwood, 1991)

16 and is the reason that land-owners install the subsurface drainage. Hydrologically, it equates

17 to the drained land having a greater unsaturated zone and therefore a larger volume of pore

18 space available for water storage prior to a rainfall event, than the undrained land. Therefore,

19 when a rainfall event does occur, saturation-excess overland flow is generated less readily on

20 the drained land, which ultimately results in the lower total discharge and the lower peak

21 discharge on the drained land during a rainfall event. This drainage effect is only valid for

22 rainfall events that are preceded by a period of little or no rainfall where the drainage has the

23 opportunity to lower the zone of saturation prior to the next event. If the rainfall event

24 happens before this has occurred (i.e. on saturated drained land) then the hydrological 
response will be similar on drained and undrained land. This can be seen in the 1st December 2005 event.

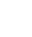

Second, the hydrological pathways can influence erosion and the export of SS and TP. On undrained land, the runoff moves laterally through the soil as throughflow, and laterally over the soil surface as overland flow (combined as interflow). On drained land, runoff can move in both of the above pathways, but in addition, can move in the subsurface drain pathway. For the events discussed in this paper, the drain pathway carries $50-66 \%$ of the total discharge from the drained land. However, this pathway only exports between $24-38 \%$ of the SS, and $29-41 \%$ of the TP, from drained land. Statistical T-tests show that there is a significant difference $(\mathrm{p}<0.001)$ between the SS and TP loads of the interflow and drainflow pathway of drained land for all events. This suggests that the drainflow pathway is a less important source of SS and TP than the enriched interflow pathway and thus by introducing the drainflow pathway to land (through the installation of subsurface drainage) we reduce the threat to water quality, partly by routing the runoff through a less erodible pathway. This is in agreement with a study by Haygarth et al. (1998) which investigated forms of phosphorus transfer from drained and undrained field lysimeters at the Rowden site, concluding that drainage reduced the annual transfer of TP by about $30 \%$. However, these findings are contrary to the claims of some workers (e.g. Chapman et al., 2001; Dils and Heathwaite, 1999; Øygarden et al., 1997), who, based on monitoring of concentrations of sediments and/or P in drainflow, suggest that drains act as a preferential pathway, increasing their export. These workers however, could not assess the overall effect of drainage on sediment or P export, due to their experimental design which typically just quantified and compared concentrations or loads of SS and/or P in surface pathways versus subsurface drain pathways without providing a proper comparison of total exports from drained versus undrained land. Nevertheless, we may expect to find 
1 different conclusions from research on sites with different soils, topography, climate and

2 drainage design.

\section{Conclusions}

4 This data set is the first to assess the contribution of drained and undrained, intensively

5 managed grasslands to sediment-related water quality problems. It shows that contrary to

6 conventional understanding, intensively managed grasslands do erode and do present a

7 significant environmental threat to water quality in terms of sediment-related water quality

8 issues. Results from this study suggest that the presence of subsurface drainage may reduce

9 the export of SS and P from grasslands. However, more work of this nature must be carried

10 out at larger scales (Brazier et al., 2007) and on different soil types (Chardon and Schoumans,

11 2007) as these have been identified as being key modulating factors which could alter the

12 patterns presented here.

13 Whilst pristine ungrazed grassland may not suffer from erosion problems, the presence of

14 grazing animals (particularly at higher stocking densities) can enhance rates of erosion and the delivery of suspended solids and sorbed contaminants to surface waters. Due to the limited availability of agricultural land in many regions and the ever increasing demand for agricultural produce, very little grassland remains in its natural ungrazed state. Therefore, it is

18 likely that globally, grasslands are contributing significant volumes of suspended solids and 19 sorbed contaminants to catchment surface waters. Whilst conversion from arable land to pristine grassland may prevent erosion problems, conversion to intensively managed agricultural grassland, which should be regarded as the more realistic conversion scenario given the demands for produce, may not solve erosion problems if the dynamics reported here are broadly applicable. Failure to acknowledge these findings will undoubtedly result in the non-compliance of surface waters to water quality standards. 
FOR JOURNAL OF ENVIRONMENTAL QUALITY 


\section{Acknowledgments}

This paper arises from Research funded by Defra (project PEO 120). IGER is grateful for core support from the Biotechnology and Biological Sciences Research Council. We are grateful to Sue Rouillard of University of Exeter, for compiling figures 1, 3 and 4.

\section{References}

Alström, K., and Åkerman, A.B. 1992. Contemporary soil erosion rates on arable land in Southern Sweden. Geografiska Annaler Series A 74:101-108.

Anon. 1980. Suspended, settleable, and total dissolved solids in waters and effluents. Methods for the examination of waters and associated materials. Her Majesty's Stationery Office, London.

Armstrong, A.C. 1986. Mole drainage of a Hallsworth Series soil. Soil Use Manage. 2:54 -58.

Armstrong, A.C., and Garwood, E.A. 1991. Hydrologic consequences of artificial drainage of grassland. Hydrological Processes. 5:157-174.

Avery, B.W. 1980. A soil classification for England and Wales, Harpenden.

De Baets, S., Poesen, J., Gyssels, G. and Knapen, A. 2006. Effects of grass roots on the erodibility of topsoils during concentrated flow. Geomorphology. 76:54-67.

Bilotta, G.S., Brazier, R.E., and Haygarth, P.M. 2007. The impacts of grazing animals on the quality of soils, vegetation and surface waters in intensively managed grasslands. Advances In Agronomy 94:237-280.

Boardman, J., and Evans, R. 1994. Soil erosion in Britain- a review. In: Rickson R.J. (Editor), Conserving Soil Resources: European Perspectives. CABI, Wallingford, pp. 3-12.

Boorman, D.B., Hollis, J.M., and Lilly, A. 1995. Hydrology of soil types: a hydrologically based classification of the soils of the United Kingdom., Institute of Hydrology Natural Environmental Research Council, Wallingford.

Brazier, R.E. 2004. Quantifying soil erosion by water in the UK: a review of monitoring and modelling approaches. Progress in Physical Geography, 28:340-365.

Brazier, R.E., Bilotta, G.S., and Haygarth, P.M. 2007. A perspective on the role of lowland, agricultural grasslands in contributing to erosion and water quality problems in the UK. Earth Surface Processes and Landforms 32:964 -967.

Chapman, A.S., Foster, I.D.L., Lees, J.A., Hodgkinson, R.A., and Jackson, R.H. 2001. Particulate phosphorus transport by subsurface drainage from agricultural land in the UK. Environmental significance at the catchment and national scale. The Science of The Total Environment 266:95-102.

Chardon, W.J., and Schoumans, O.F. 2007. Soil texture effects on the transport of phosphorus from agricultural land in river deltas of Northern Belgium, The Netherlands, and North-West Germany. Soil Use Manage. 23:16-24.

Davies, K., Fullen, M.A., and Booth, C.A. 2006. A pilot project on the potential contribution of palm-mat geotextiles to soil conservation. Earth Surface Processes and Landforms 31:561-569.

Defra, 2003. Water, Air and Soil Codes. Codes of Good Agricultural Practice: Summary. In: F.A.R.A. Department for the Environment (Editor).

Dils, R.M., and Heathwaite, A.L. 1999. The controversial role of tile drainage in phosphorus export from agricultural land. Water Science and Technology 39:55-61.

Eisenrich, S.J., Bannerman, R.T. and Armstrong, D.E. 1975. A simplified phosphorus analysis technique. Environmental Letters 9:43-53. 
Evans, R. 2005. Monitoring water erosion in lowland England and Wales - a personal view of its history and outcomes. CATENA 64:142-161.

Fullen, M.A. 1992. Erosion rates on bare loamy soils in east Shropshire, UK. Soil Use Manage. 8:157-162.

Fullen, M.A., Booth, C.A., and Brandsma, R.T. 2006. Long-term effects of grass ley set-aside on erosion rates and soil organic matter on sandy soils in east Shropshire, UK. Soil and Tillage Research 89:122-128.

Gammon, J.R. 1970. The effect of inorganic sediment on stream biota. Washington D.C.

Hart, I.D.M. 1979. The effects of altering runoff characteristics. Letter in New Civil Engineering 66.

Haygarth, P.M., Ashby, C.D., and Jarvis, S.C. 1995. Short term changes in the molybdate reactive phosphorus of stored soil waters. Journal of Environmental Quality 24:11331140.

Haygarth, P.M., Bilotta, G.S., Bol, R., Brazier, R.E., Freer, J., Gimbert, L., Granger, S., Krueger, T., Macleod, C., Naden, P., Quinton, J., Smith, B., Worsfold, P. 2006. Processes affecting transfer of sediment and colloids, with associated phosphorus, from intensively farmed grasslands: An overview of key issues. Hydrological Processes 20:4407-4413.

Haygarth, P.M., Hepworth, L., and Jarvis, S.C. 1998. Forms of phosphorus transfer in hydrological pathways from soil under grazed grassland. European Journal of Soil Science 49:65-72.

Heathwaite, L., Haygarth, P., Matthews, R., Preedy, N. and Butler, P., 2005. Evaluating colloidal phosphorus delivery to surface waters from diffuse agricultural sources. Journal of Environmental Quality, 34: 287-298.

Howe, G.M., Slaymaker, H.O., and Harding, D.M. 1967. Some aspects of the flood hydrology of the Upper Severn and Wye. Transactions of the Institute of British Geographers 41:33-58.

Kronvang, B., Laubel, A. and Grant, R. 1997. Suspended sediment and particulate phosphorus transport and delivery pathways in an arable catchment, Gelbaek Stream, Denmark. Hydrological Processes 11:627-642.

Krueger, T., Quinton, J., Freer, J., Macleod, C., Bilotta, G.S., Brazier, R.E., Butler, P., Granger, S., Haygarth, P.M. 2007. Inferring processes of sediment and phosphorus transfer from replicated, intensive grassland plots. Heckrath, G., Rubaek, G.H., Kronvang, B. (eds). Diffuse Phosphorus Loss: Risk assessment, mitigation options and ecological effects in river basins. pp 462.

Morgan, R.P.C. 2005. Soil erosion and conservation. Blackwell Publishing, Oxford. 304 pp.

Morgan, R.P.C., and Rickson, R.J. 1995. Slope stabilization and erosion control: A Bioengineering Approach. Chapman and Hall, London.

Murphy, J., and Riley, J.P. 1962. A modified single solution method for the determination of phosphate in natural waters. Anal. Chim. Acta. 27:31-36.

Nash, D.M., and Halliwell, D.J. 1999. Fertilisers and phosphorus loss from productive grazing systems. Australian Journal Of Soil Research 37:403-429.

Neal, C., and Jarvie, H.P. 2005. Agriculture, community, river eutrophication and the Water Framework Directive. Hydrological Processes 19:1895-1901.

OECD. 1982. Eutrophication of waters, monitoring, assessment and control, Organisation for Economic Cooperation and Development, Paris.

Oliver, D.M., Clegg, C.D., Haygarth, P.M., and Heathwaite, A.L. 2005. Assessing the potential for pathogen transfer from grassland soils to surface waters. Advances in Agronomy 85:125-180. 
Pan, C., and Shangguan, Z. 2006. Runoff hydraulic characteristics and sediment generation in sloped grassplots under simulated rainfall conditions. Journal of Hydrology 331:178185.

Pappenberger, F., Matgen, P., Beven, K., Henry, J.B., Pfister, L., and de Fraipont, P. 2006. Influence of uncertain boundary conditions and model structure on flood inundation predictions. Advances in Water Resources 29:1430-1449.

Pearce, R.A., Trlica, M.J., Leininger, W.C., Smith, J.L., and Frasier, G.W. 1997. Efficiency of grass buffer strips and vegetation height on sediment filtration in laboratory rainfall simulations. Journal of Environmental Quality 26:139-144.

Peeters, A. 2004. Wild and sown grasses. Profiles of a temperate species selection; Ecology, biodiversity and use. Blackwell, London.

Reynolds, S.G., and Frame, J. 2005. Grasslands: Developments, opportunities, perspectives. Science Publishers Inc., Plymouth. 539 pp.

Robinson, M., Ryder, E.L., and Ward, R.C. 1985. Influence on streamflow of field drainage in a small agricultural catchment. Agricultural Water Management 10:145-158.

Ryan, P.A. 1991. Environmental Effects of sediment on New Zealand Streams: a review. New Zealand Journal of Marine and Freshwater Research 25:207-221.

Scholefield, D., Tyson, K.C., Garwood, E.A., Armstrong, A.C., Hawkins, J., Stone, A.C. 1993. Nitrate leaching from grazed grassland lysimeters - effects of fertilizer input, field drainage, age of sward and patterns of weather. Journal of Soil Science 44:601613.

Sharpley, A.N., Foy, R.H., and Withers, P.J.A. 2000. Practical and innovative measures for the control of agricultural phosphorus losses to water. An Overview. Journal of Environmental Quality 29:1-9.

Smith, L.P., and Trafford, B.D. 1976. Climate and Drainage, London.

U.S. Environmental Protection Agency, 2007. www.epa.gov/ost/standards/nutrient.html.

USDA. 1975. Soil conservation service Soil Taxonomy: a basic system for soil classification for making and interpreting soil surveys, New York.

Wilkins, R.J. 1982. The permanent grassland division at North Wyke., The Grassland Research Institute, Hurley.

Withers, P.J.A., Hodgkinson, R.A., Bates, A., and Withers, C.M. 2006. Some effects of tramlines on surface runoff, sediment and phosphorus mobilization on an erosionprone soil. Soil Use Manage 22:245-255.

Øygarden, L., Kværner, J. and Jenssen, P.D., 1997. Soil erosion via preferential flow to drainage systems in clay soils. Geoderma 76:65-86. 


\section{List of Figures}

Figure 1: A location map and aerial photograph of the Rowden field-site, Devon, UK. Where (A) is the drained 1-ha lysimeter, and (B) is the undrained 1-ha lysimeter. (see separate pdf)

Figure 2: Schematic cross-section of undrained and drained field-scale lysimeters at Rowden, showing the hydrological pathways and flow measurement system. Adapted from Armstrong and Garwood (1991) (see separate pdf).

Figure 3: Hydrographs (uncertainty is illustrated using the minimum and maximum discharges) of undrained (top), and drained (bottom), 1-ha grassland lysimeters in response to a natural rainfall event that occurred between 01:00 and 17:53 hrs on the $7^{\text {th }}$ March 2006. (see see separate $\mathrm{pdf}$ )

Figure 4: Hydrograph of the 2005-2006 hydrological season on the drained lysimeter. The data is compiled from hourly instantaneous data derived from the polynomial fit (h-Q). (see separate pdf)

\section{List of Tables}

Table 1: Summary Table for storm event budget data of drained and undrained 1 ha grassland lysimeters. 
FOR JOURNAL OF ENVIRONMENTAL QUALITY

1

2 
FOR JOURNAL OF ENVIRONMENTAL QUALITY

Table 1: Summary Table for storm event budget data of drained and undrained 1 ha grassland lysimeters.

\begin{tabular}{|c|c|c|c|c|c|c|c|c|c|c|c|c|c|c|c|}
\hline \multirow{2}{*}{$\begin{array}{l}\text { Storm Date } \\
\text { dd/mm/yy }\end{array}$} & \multirow{2}{*}{$\begin{array}{c}\begin{array}{c}\text { Event } \\
\text { Rainfall }\end{array} \\
\mathrm{mm}\end{array}$} & \multirow[t]{2}{*}{$\begin{array}{l}\text { Drainage } \\
\text { Status }\end{array}$} & \multirow{2}{*}{$\begin{array}{c}\begin{array}{c}\text { Peak Q } \\
(\neq \neq)\end{array} \\
\mathrm{L} \mathrm{s}^{-1}\end{array}$} & \multicolumn{2}{|c|}{$\begin{array}{c}\text { Lag Time } \\
(\dagger \dagger)\end{array}$} & \multirow{2}{*}{$\begin{array}{c}\text { Total Event Q } \\
(\dagger) \\
1000 \mathrm{~L}\end{array}$} & \multirow{2}{*}{$\begin{array}{c}\% \text { Total Q } \\
\text { via IF } \\
(\neq)\end{array}$} & \multirow[t]{2}{*}{$\begin{array}{l}\text { SS Export } \\
(\neq \neq)\end{array}$} & \multicolumn{2}{|c|}{$\begin{array}{c}\% \mathrm{SS} \\
\text { Export as } \\
\text { VOM }\end{array}$} & \multirow{2}{*}{$\begin{array}{c}\% \text { SS } \\
\begin{array}{r}\text { Export } \\
\text { via IF }\end{array} \\
\%\end{array}$} & \multirow{2}{*}{$\begin{array}{c}\text { TP Export } \\
(\neq \neq) \\
\mathrm{g}\end{array}$} & \multicolumn{2}{|c|}{$\begin{array}{c}\% \mathrm{TP} \\
\text { Export as } \\
\text { MRP } \\
\end{array}$} & \multirow{2}{*}{$\begin{array}{c}\% \mathrm{TP} \\
\text { Export via } \\
\text { IF } \\
\%\end{array}$} \\
\hline & & & & $\mathrm{mi}$ & & & & & & & & & & & \\
\hline \multirow[t]{2}{*}{$01 / 12 / 05$} & 10.16 & Undrained & 13.5 & & 27 & $\begin{array}{c}127 \\
(111-146)\end{array}$ & 100 & $\begin{array}{c}\mathbf{4 . 7 7} \\
(4.14-5.45)\end{array}$ & & 34 & 100 & $\begin{array}{c}\mathbf{2 5 . 6 7} \\
(22.43- \\
29.45)\end{array}$ & & $\mathrm{n} / \mathrm{a}$ & 100 \\
\hline & & Drained & 9.2 & $\begin{array}{l}\text { IF } \\
\text { DF }\end{array}$ & $\begin{array}{l}30 \\
43\end{array}$ & $\begin{array}{c}117 \\
(106-136)\end{array}$ & $\begin{array}{c}\mathbf{3 4} \\
(35,35)\end{array}$ & $\begin{array}{c}\mathbf{4 . 6 1} \\
(4.26-5.39)\end{array}$ & $\begin{array}{l}\text { IF } \\
\text { DF }\end{array}$ & $\begin{array}{l}23 \\
51\end{array}$ & $\begin{array}{c}\mathbf{6 4} \\
(65,64)\end{array}$ & $\begin{array}{c}\mathbf{1 9 . 2 4} \\
(17.75- \\
22.53)\end{array}$ & $\begin{array}{l}\text { IF } \\
\text { DF }\end{array}$ & $\begin{array}{l}\mathrm{n} / \mathrm{a} \\
\mathrm{n} / \mathrm{a}\end{array}$ & $\begin{array}{c}59 \\
(60,60)\end{array}$ \\
\hline \multirow[t]{2}{*}{$07 / 12 / 05$} & 10.67 & Undrained & 13.5 & & 19 & $\begin{array}{c}110 \\
(96-127)\end{array}$ & 100 & $\begin{array}{c}\mathbf{9 . 2 2} \\
(8.00-10.51)\end{array}$ & & 14 & 100 & $\mathrm{n} / \mathrm{a}$ & & $\mathrm{n} / \mathrm{a}$ & $\mathrm{n} / \mathrm{a}$ \\
\hline & & Drained & 6.8 & $\begin{array}{l}\text { IF } \\
\text { DF }\end{array}$ & $\begin{array}{l}15 \\
36\end{array}$ & $\begin{array}{c}76 \\
(67-88)\end{array}$ & $\begin{array}{c}\mathbf{3 4} \\
(35,35)\end{array}$ & $\begin{array}{c}\mathbf{3 . 7 7} \\
(3.36-4.41)\end{array}$ & $\begin{array}{l}\text { IF } \\
\text { DF }\end{array}$ & $\begin{array}{l}13 \\
21\end{array}$ & $\begin{array}{c}\mathbf{6 7} \\
(68,68)\end{array}$ & $\mathrm{n} / \mathrm{a}$ & $\begin{array}{l}\text { IF } \\
\text { DF }\end{array}$ & $\begin{array}{l}\mathrm{n} / \mathrm{a} \\
\mathrm{n} / \mathrm{a}\end{array}$ & $\mathrm{n} / \mathrm{a}$ \\
\hline \multirow[t]{2}{*}{$14 / 02 / 06$} & 19.81 & Undrained & 15.8 & & 48 & $\begin{array}{c}175 \\
(149-198)\end{array}$ & 100 & $\begin{array}{c}\mathbf{1 4 . 8 5} \\
(12.59-16.75)\end{array}$ & & 17 & 100 & $\begin{array}{c}\mathbf{4 9 . 5 6} \\
(42.12 .- \\
55.92)\end{array}$ & & 11 & 100 \\
\hline & & Drained & 8.4 & $\begin{array}{l}\mathrm{IF} \\
\mathrm{DF}\end{array}$ & $\begin{array}{l}50 \\
62\end{array}$ & $\begin{array}{c}97 \\
(88-112)\end{array}$ & $\begin{array}{c}\mathbf{5 0} \\
(50,50)\end{array}$ & $\begin{array}{c}\mathbf{7 . 8 0} \\
(7.08-9.06)\end{array}$ & $\begin{array}{l}\text { IF } \\
\text { DF }\end{array}$ & $\begin{array}{l}19 \\
21\end{array}$ & $\begin{array}{c}\mathbf{6 2} \\
(63,63)\end{array}$ & $\begin{array}{c}\mathbf{3 0 . 4 3} \\
(27.79- \\
35.39)\end{array}$ & $\begin{array}{l}\mathrm{IF} \\
\mathrm{DF}\end{array}$ & $\begin{array}{r}14 \\
\mathrm{n} / \mathrm{a}\end{array}$ & $\begin{array}{c}\mathbf{6 0} \\
(61,60)\end{array}$ \\
\hline \multirow[t]{2}{*}{ 07/03/06 } & 11.43 & Undrained & 8.6 & & 21 & $\begin{array}{c}\mathbf{1 0 3} \\
(91-120)\end{array}$ & 100 & $\begin{array}{c}\mathbf{6 . 2 0} \\
(5.49-7.21)\end{array}$ & & 17 & 100 & $\begin{array}{c}\mathbf{1 9 . 1 1} \\
(16.93- \\
22.20)\end{array}$ & & 14 & 100 \\
\hline & & Drained & 3.2 & $\begin{array}{l}\text { IF } \\
\text { DF }\end{array}$ & $\begin{array}{l}26 \\
35\end{array}$ & $\begin{array}{c}52 \\
(42-60)\end{array}$ & $\begin{array}{c}\mathbf{4 7} \\
(51,49)\end{array}$ & $\begin{array}{c}\text { 3.01 } \\
(2.55-3.58)\end{array}$ & $\begin{array}{l}\text { IF } \\
\text { DF }\end{array}$ & $\begin{array}{l}19 \\
21\end{array}$ & $\begin{array}{c}\mathbf{7 1} \\
(74,73)\end{array}$ & $\begin{array}{c}9.41 \\
(8.02- \\
11.08)\end{array}$ & $\begin{array}{l}\text { IF } \\
\text { DF }\end{array}$ & $\begin{array}{l}12 \\
13\end{array}$ & $\begin{array}{c}\mathbf{7 1} \\
(74,73)\end{array}$ \\
\hline \multirow[t]{2}{*}{ 08/03/06 } & 7.87 & Undrained & 12.5 & & 26 & $\begin{array}{c}96 \\
(82-110)\end{array}$ & 100 & $\begin{array}{c}\mathbf{7 . 4 9} \\
(6.29-8.50)\end{array}$ & & 17 & 100 & $\begin{array}{c}\mathbf{1 7 . 7 0} \\
(15.00- \\
20.14)\end{array}$ & & 18 & 100 \\
\hline & & Drained & 5.3 & $\begin{array}{l}\text { IF } \\
\text { DF }\end{array}$ & $\begin{array}{l}26 \\
58\end{array}$ & $\begin{array}{c}69 \\
(59-79)\end{array}$ & $\begin{array}{c}\mathbf{4 4} \\
(47,46)\end{array}$ & $\begin{array}{c}\mathbf{5 . 2 7} \\
(4.77-6.16)\end{array}$ & $\begin{array}{l}\text { IF } \\
\text { DF }\end{array}$ & $\begin{array}{l}14 \\
28\end{array}$ & $\begin{array}{c}\mathbf{7 6} \\
(79,78)\end{array}$ & $\begin{array}{r}\mathbf{1 4 . 0 5} \\
(12.58 \\
16.42)\end{array}$ & $\begin{array}{l}\text { IF } \\
\text { DF }\end{array}$ & $\begin{array}{r}7 \\
11\end{array}$ & $\begin{array}{c}69 \\
(72,71)\end{array}$ \\
\hline
\end{tabular}


(†) Total Event $Q$ is rounded to the nearest $1000^{\text {th }}$ litre

$(\neq) \%$ Total $\mathrm{Q}$ via IF is the \% of the total discharge which passed through the interflow pathway.

(§) Values in bold are the values calculated using the discharge data from the classic h-Q relationship.

(II) Values in brackets are the values calculated using the discharge data from uncertainty intervals ( $\mathrm{min}-\mathrm{max}$ ).

(\#) Storm Event $=$ A period of discharge is only defined as a storm event if it exceeds $1 \mathrm{~L} \mathrm{~s}^{-1}$ for at least 60 min. Multi-peak discharges are only separated into individual events if the total discharge drops below

the $1 \mathrm{~L} \mathrm{~s}^{-1}$ threshold for more than 60 mins before rising again. The start and end times of events has been defined using the following rules:

(a) Rainfall rule : (first choice of rule)

The storm event starts $1 \mathrm{~h}$ before the hour of the first rainfall record connected to that storm ('connected' $=$ no more than $3 \mathrm{~h}$ separation with no rainfall)

The storm event ends $4 \mathrm{~h}$ after the last rainfall record related to that storm.

(b) Discharge rule : (for multi-peaked events)

The storm event starts at the time which coincides with the middle point of the lowest discharge between two successive storm events.

The storm event ends at the time which coincides with the middle point of the lowest discharge between two successive storm events.

$(\dagger)$ Lag time is the time $(\mathrm{min})$ from the first min of the peak $15 \mathrm{~min}$ rainfall intensity $(\mathrm{mm}$ per $15 \mathrm{~min}$ ) to the peak discharge $(\mathrm{Q})$

$(\#) \mathrm{Q}=$ Discharge, $\mathrm{IF}$ = Interflow, DF = Drainflow, $\mathrm{SS}=$ Suspended Solids, TP = Total Phosphorus 
FOR JOURNAL OF ENVIRONMENTAL QUALITY 